\title{
PENGARUH TEKNIK BACK MASSAGE (MASASE PUNGGUNG) TERHADAP PENURUNAN INTENSITAS NYERI PADA PASIEN POST OPERASI APPENDIKSITIS DI RSU ROYAL PRIMA MEDAN 2018
}

\author{
Tiarnida Nababan, Karmila Br Kaban, Ricky Rahmat Ndruru \\ 1,2 Dosen Fakultas Keperawatan dan Kebidanan UNPRI \\ 3 Mahasiswa S1 Keperawatan UNPRI \\ Email: tiarnidanababan@unprimdn.ac.id
}

\begin{abstract}
Pain is an unpleasant sensory and emotional experience due to actual and potential tissue damage. The technique can reduce the intensity of pain in postoperative appendicitis patients so that the therapy can provide comfort for the patient. This study aims to explore the effect of back massage technique on reducing pain intensity in patients with postoperative appendicitis. This type of research is pre-experimental using a one-group pre-post design test. The research population included 13 patients postoperative appendicitis at Royal Prima Hospital Medan in 2018. The research samples were drawn by using the Accidental Sampling technique. The research was conducted on March 2018 at Royal Prima hospital Medan. The research data were analyzed using Wilcoxon Test with a significant value of $\alpha=0.05$. The patient experienced pain before back massage was provided and after the administration of back massage technique, patient experiencing mild pain was $60 \%$ and $40 \%$ experienced moderate pain. The results of bivariate analysis showed that $p$-value $=0.034$. This showed that there was a difference between the intensity of pain before and after the back massage technique was performed in patients with postoperative appendicitis. From the results of the above research, it is suggested that the implementation of back massage techniques has an effect on the decrease in pain intensity in patients with postoperative appendicitis. This back massage technique can be applied at hospitals as a measure of pain management which is an independent action of the nurse to handle the patient's pain.
\end{abstract}

Keywords: post appendicitis, intensity pain, back massage technique

\section{PENDAHULUAN}

Derajat kesehatan masyarakat dipengaruhi oleh empat faktor utama, yakni: lingkungan, perilaku, pelayanan kesehatan, dan keturunan (herediter). Karena itu upaya untuk memelihara dan meningkatkan derajat kesehatan masyarakat harus ditujukan pada keempat faktor utama tersebut secara bersama-sama (Notoatmodjo, 2012). Salah satu penyakit yang sering terjadi di Indonesia adalah penyakit appendisitis. Menurut Mary (2014), Appendisitis adalah penyebab paling umum inflamasi akut pada kuadran kanan bawah rongga abdomen, penyebab paling umum untuk bedah abdomen darurat (Hadija, Tunny, dkk, 2016).

Apendisitis adalah peradangan dari apendik periformis, dan merupakan penyebab utama abdomen akut yang 
paling sering. Appendiksitis akut adalah keadaan yang disebabkan oleh peradangan yang mendadak oleh appendiks (Dermawan \& Rahayuningsih, 2017). Apendiktomy adalah pengangkatan terhadap apendiks terimplamasi dengan prosedur atau pendekatan endoskopi (Ratu \& Adwan, 2016).

Menurut International Association for Study of Pain (IASP), nyeri adalah sensori subjektif dan emosional yang tidak menyenangkan yang didapat terkait dengan kerusakan jaringan aktual maupun potensial, atau menggambarkan kondisi terjadinya kerusakan (Judha, dkk, 2015). Nyeri pada penderita pada penderita post operasi abdomen sering mengakibatkan pasien sulit untuk tidur dan pasien tidak dapat mengontrol rasa nyeri dengan maksimal sehingga kecenderungan mengunakan obat analgesik (Astarani \& Fitriana, 2015).

Angka kejadian appendisitis cukup tinggi didunia. Berdasarkan Word Health Organisation (2010) yang dikutip oleh Naulibasa (2011), angka mortalitas akibat appendisitis adalah 21.000 jiwa, dimana populasi laki-laki lebih banyak dibandingkan populasi perempuan. Terdapat 70.000 kasus appendisitis di Amerika Serikat tiap tahunnya (Sulung \& Rani, 2017). Menurut Eylin (2009) dan Andika (2016), kejadian appendisitis di Amerika
Serikat memiliki insiden 1-2 kasus per 10.000 anak pertahunnya antara kelahiran sampai umur 4 tahun. Kejadian appendisitis meningkat 25 kasus per 10.000 jiwa anak pertahun antara umur 10-17 tahun di Amerika Serikat. Apabila dirata-rata apendisitis 1,1 kasus per 1000 orang pertahun di Amerika Serikat (Sulung \& Rani, 2017).

Sedangkan insiden apendisitis di Asia pada tahun 2008 menurut WHO adalah $4,8 \%$ penduduk dari total populasi. Menurut kemenkes RI pada tahun 2012 apendisitis menduduki urutan ke empat penyakit terbanyak setelah dispepsia, gastritis, duodenitis, dengan jumlah pasien rawat inap sebanyak 2840. Selain itu pada tahun 2013 insidensi apendisitis di Indonesia menempati urutan tertinggi di antara kasus US kegawatan abdomen lainnya. Insiden terjadinya appendisitis di negara maju lebih tinggi dibandingkan dengan Negara berkembang (Hadija, Tunny, dkk, 2016).

Data Kemenkes RI (2013), sementara di Indonesia sendiri appendisitis merupakan penyakit dengan urutan keempat terbanyak pada tahun 2010. Data yang dirilis oleh Kemenkes RI pada tahun 2011 jumlah penderita appendisitis di Indonesia mencapai 591.819 orang dan meningkat pada tahun 2012 sebesar 596.132 orang. Kelompok usia yang umumnya 
mengalami appendisitis yaitu pada usia 10-30 tahun. Dimana insiden laki-laki lebih tinggi daripada perempuan (Hadija, Tunny, dkk, 2016).

Dinas Kesehatan Sumatera Barat menyebutkan bahwa pada tahun 2014 jumlah kasus appendisitis sebanyak 5.980 penderita, dan 177 penderita diantaranya menyebabkan kematian. Dari data di RSUD. Achmad Mochtar pada tahun 2014 angka kejadian appendiksitis sebanyak 493 pasien dengan rincian 221 pria dan 272 wanita, dan pada tahun 2015 angka kejadian appendiksitis sebanyak 521 pasien dengan 204 pria dan 317 wanita dan 2 tahun berturut-turut ada 7 pasien yang meninggal dunia (Sulung, dkk, 2017).

Hasil survei yang dilakukan peneliti pada tanggal 1 Maret 2018 di RSU. Royal Prima Medan didapat kasus post operasi appendiksitis dari bulan Januari sampai bulan Februari tahun 2018 sebanyak 13 orang yang menjalani rawat inap. Maka peneliti sangat tertarik untuk mengetahui "Pengaruh Teknik Back massage Terhadap Penurunan Intensitas Nyeri Pada Pasien Post Operasi Appendiksitis Di Rumah Sakit Royal Prima Medan Tahun 2018”.

\section{METODE}

Jenis penelitian ini adalah penelitian pre-eksperimen dengan menggunakan rangcangan one-group pres-post tes design yaitu penelitian yang tidak memiliki kelompok pembanding (kontrol), tetapi paling tidak sudah dilakukan observasi pertama (pretest) yang memungkinkan menguji perubahan-perubahan yang terjadi setelah adanya eksperimen (program). Penelitian ini, sebelum dilakukan teknik back massage (pre-test) maka intensitas nyeri pada pasien post operasi appendiksitis dikaji terlebih dahulu, kemudian dilakukan teknik back massage selama 10-15 menit oleh peneliti, setelah itu dikaji kembali (posttest) intensitas nyeri pada pasien post operasi appendiksitis tersebut.

Penelitian ini dilakukan di seluruh ruangan rawat inap Rumah Sakit Royal Prima Medan Daerah Jalan Ayahanda No.68 A, Sei Putih Tengah, Medan Petisah, Kota Medan.

Populasi penelitian ini adalah seluruh pasien post operasi appendiksitis yang di rawat inap di Rumah Sakit Royal Prima Medan Daerah jalan Ayahanda No.68 A, Sei Putih Tengah, Medan Petisan, Kota Medan. Dengan jumlah populasi pasien post operasi appendiksitis dari bulan Januari sampai Februari tahun 2018 adalah sebanyak 13 orang. Teknik dalam pengambilan sampel ini adalah “Accidental Sampling”. Kriteria sampel antara lain pasien post operasi appendiksitis, dan menjalani rawat inap lebih dari 3 hari. 
Data yang digunakan dalam penelitian ini yaitu data primer, melalui teknik wawancara langsung kepada responden dengan menggunakan kuesioner.

Teknik analisa data menggunakan analisa univariat dan bivariat. Analisis univariat Analisis univariate bertujuan untuk menjelaskan atau mendeskripsikan karakteristik setiap variabel penelitian. Analisis bivariat menggunakan uji wilcoxon untuk menguji beda mean peringkat (data ordinal) dari dua hasil pengukuran pada kelompok yang sama (beda peringkat pre test dan post test), dengan derajat kemaknaan $(\alpha) 0,05$.

\section{HASIL DAN PEMBAHASAN}

Hasil

Tabel 1.

Intensitas Nyeri pada Pasien Appendiksitis Sebelum Dilakukan Teknik Back Massage

\begin{tabular}{clcc}
\hline No. & $\begin{array}{c}\text { Nyeri Post } \\
\text { Operasi } \\
\text { Appendiksitis }\end{array}$ & $\begin{array}{c}\text { Jumlah } \\
\text { (n) }\end{array}$ & $\begin{array}{c}\text { Persentase } \\
(\mathbf{\%})\end{array}$ \\
\hline 1 & $\begin{array}{l}\text { Nyeri } \\
\text { ringan }\end{array}$ & 0 & 0 \\
2 & $\begin{array}{l}\text { Nyeri } \\
\text { sedang }\end{array}$ & 5 & 100 \\
3 & Nyeri berat & 0 & 0 \\
\hline & \multicolumn{1}{c}{ Total } & $\mathbf{5}$ & $\mathbf{1 0 0}$ \\
\hline
\end{tabular}

Berdasarkan tabel $1 \mathrm{di}$ atas diketahui bahwa sebelum dilakukan teknik back massage pada pasien post operasi appendisitis dari 5 responden yang mengalami nyeri sedang post operasi appendiksitis sebanyak 5 orang (100\%), nyeri berat post operasi apendiksitis sebanyak $0(0 \%)$, dan nyeri ringan post operasi appendiksitis tidak ada.

Tabel 2.

Intensitas Nyeri pada Pasien Appendiksitis Setelah Dilakukan Teknik Back Massage

\begin{tabular}{clcc}
\hline No. & $\begin{array}{c}\text { Nyeri Post } \\
\text { Operasi } \\
\text { Appendiksitis }\end{array}$ & $\begin{array}{c}\text { Jumlah } \\
(\mathbf{n})\end{array}$ & $\begin{array}{c}\text { Persentase } \\
(\boldsymbol{\%})\end{array}$ \\
\hline 1 & $\begin{array}{l}\text { Nyeri } \\
\text { ringan }\end{array}$ & 3 & 60 \\
2 & $\begin{array}{l}\text { Nyeri } \\
\text { sedang }\end{array}$ & 2 & 40 \\
3 & Nyeri berat & 0 & 0 \\
\hline & \multicolumn{1}{c}{ Total } & $\mathbf{5}$ & $\mathbf{1 0 0}$ \\
\hline
\end{tabular}

Berdasarkan tabel 2 di atas diketahui bahwa setelah dilakukan teknik back massage pada pasien post operasi apendiksitis dari 5 responden yang mengalami nyeri sedang post operasi appendiksitis sebanyak 2 orang (40\%), nyeri berat post operasi apendiksitis sebanyak $0(0 \%)$, dan nyeri ringan post operasi appendiksitis sebanyak 3 orang $(60 \%)$.

Berikut ini merupakan tabel pengaruh teknik back massage terhadap penurunan intensitas nyeri pada pasien post operasi appendiksitis di RSU. Royal Prima Medan tahun 2018. 
Tabel 3.

Pengaruh Teknik Back Massage Terhadap Penurunan Intensitas Nyeri Pada Pasien Post Operasi Appendiksitis di RSU. Royal Prima Medan Tahun 2018

\begin{tabular}{cccccc}
\hline $\begin{array}{c}\text { Teknik Back } \\
\text { Massage }\end{array}$ & N & Mean & Median & $\mathbf{Z}$ & P value \\
\cline { 1 - 4 } Pretest & 5 & 5,20 & 5,00 & -2.121 & 0,034 \\
\hline Postest & 5 & 3,40 & 3,00 & & \\
\hline
\end{tabular}

Berdasarkan 3 diatas dapat dilihat bahwa hasil uji Wilcoxon pada saat uji pre test nilai mean 5,20 dan nilai median 5. Pada saat uji post test nilai mean adalah 3,40 dan nilai median adalah 3 . Maka nilai $\mathrm{Z}=-2.121$ dengan nilai $\mathrm{p}$ value sebesar 0,034 , hal ini berarti $\mathrm{p}$ value $<\alpha(0,05)$ sehingga Ho ditolak dan Ha diterima jadi dapat disimpulkan bahwa terdapat pengaruh teknik back massage terhadap penurunan intensitas nyeri pada pasien post operasi di RSU. Royal Prima Medan tahun 2018.

\section{Pembahasan}

Berdasarkan uji Wilcoxon menunjukan bahwa nilai $\mathrm{Z}=-2,121$ signifikasi $\mathrm{p}$-value sebesar 0,034 hal ini berarti $\mathrm{p}$-value $<\alpha(0,05)$ sehingga $\mathrm{Ho}$ ditolak dan $\mathrm{Ha}$ diterima menunjukan bahwa terdapat pengaru teknik back massage terhadap penurunan intensitas nyeri pada pasien post operasi di RSU. Royal Prima Medan tahun 2018.

Peneliti melakukan penelitian pada 5 orang responden dengan menggunakan alat dan bahan yang sama yaitu minyak kayu putih agar setiap responden mendapatkan perlakuan yang sama sehingga hasil yang diperoleh dapat maksimal. Sebanyak 5 orang responden, 3 orang laki-laki dan 2 orang perempuan. Pada responden laki-laki, tindakan yang diberikan langsung dilakukan oleh peneliti akan tetapi pada responden perempuan tindakan yang diberikan dilakukan oleh keluarga karena responden tidak berterima atau bersedia menjadi responden apabila tindakan dilakukan langsung oleh peneliti karena peneliti adalah seorang laki-laki. Tindakan yang diberikan kepada semua responden adalah back massage dengan metode petrissage (pijatan) dengan tekan ringan sampai sedang selama 15 menit dan dilakukan oleh orang yang berbeda.

Sebelum dilakukan tindakan back massage mayoritas responden berskala nyeri sedang. Setelah selesai dilakukan tindakan back massage ternyata hasil yang diperoleh sangat memuaskan dimana 3 orang responden berskala nyeri ringan dan 2 orang responden berskala nyeri sedang. Walaupun pada responden perempuan hasil yang 
didapatkan kurang memuaskan seperti pada responden laki-laki. Hal ini disebabkan karena adanya perbedaan antara kekuatan tangan peneliti dengan tangan keluarga yang melakukan tindakan pada responden.

Mekanisme penurunan nyeri ini dapat dijelaskan dengan teori gate control yaitu intensitas nyeri diturunkan dengan dengan memblok transmisi nyeri pada gerbang (gate) dan teori Endorphin yaitu menurunnya intensitas nyeri dipengaruhi oleh meningkatnya kadar endorphin dalam tubuh. Dengan pemberian terapi back massage dapat merangsang serabut A beta yang banyak terdapat di kulit dan berespon terhadap masase ringan pada kulit sehingga impuls dihantarkan lebih cepat. Pemberian stimulasi ini membuat masukan impuls dominan berasal dari serabut A beta sehingga pintu gerbang menutup dan impuls nyeri tidak dapat diteruskan ke korteks serebral untuk diinterpretasikan sebagai nyeri.

Di samping itu, sistem kontrol desenden juga akan bereaksi dengan melepaska endorphin yang merupakan morfin alami tubuh sehingga memblok transmisi nyeri dan persepsi nyeri tidak terjadi, jadi intensitas yang dirasakan mengalami penurunan.

Hasil penelitian dari Wirya \& Sari (2013) tentang pengaruh pemberian massage punggung dan teknik relaksasi nafas dalam terhadap penurunan intensitas nyeri pada pasien post apendiktomi di Zaal C RS HKBP Balige tahun 2011 menunjukan hasil yang signifikan pengaruh massage punggung dan teknik relaksasi nafas dalam terhadap penuruna intensitas nyeri. Hasil analisa data dengan mengunakan uji $T$ Berpasangan didapatkan nilai $\mathrm{P}=0,017$ $<\alpha=0,05$.

Sedangkan hasil penelitian ini sejalan dengan penelitian Astarani \& Fitriana (2015) tentang terapi back massage menurunkan nyeri pada pasien post operasi abdomen di Instalasi Rawat Inap RS Baptis Kediri menunjukkan hasil yang signifikan pengaruh teknik back massage terhadap penurunan intensitas nyeri. Hasil analisa data dengan mengunakan uji statistik wilcoxon Sign rank test diperoleh nilai $\alpha=0,05$ didapatkan $Z=-5.470$ dan $\rho=0,000$.

Penelitian ini menjelaskan bahwa terapi teknik back massage merupakan salah satu terapi yang efektif untuk menurunkan intensitas nyeri sebab teknik ini mudah untuk dilakukan dan tidak membutuhkan tempat yang luas serta alat-alatnya yang murah dan mudah didapatkan sehingga cocok dilakukan oleh semua orang terutama pada pasien yang telah menjalani operasi appendiksitis. 


\section{KESIMPULAN DAN SARAN}

\section{Kesimpulan}

1. Hasil penelitian sebelum dilakukan teknik back massage diketahui bahwa intensitas nyeri pada pasien post operasi appendiksitis mayoritas berskala nyeri sedang.

2. Hasil penelitian setelah dilakukan teknik back massage diketahui bahwa intensitas nyeri pada pasien post operasi appendiksitis mayoritas berskala nyeri ringan.

3. Ada pengaruh teknik back massage terhadap penurunan intesitas nyeri pada pasien post operasi appendiksitis di RSU. Royal Prima Medan tahun 2018

\section{Saran}

1. Bagi Institusi Pelayanan Rumah

\section{Sakit}

Bagi Institusi Pelayanan Rumah Sakit diharapkan untuk dapat menerapkan teknik back massage sebagai salah satu alternatif terapi yang efektif dan efesien dalam menurunkan intensitas nyeri pada pasien post operasi appendiksitis.

\section{Bagi Responden}

Bagi pasien hendaknya dapat menerapkan teknik back massage dengan teratur untuk menurunkan intensitas nyeri sehingga memberi rasa nyaman. Responden diharapkan dapat mengaplikasinya setelah pulang ke rumah.

\section{Penelitian Selanjutnya}

Hasil penelitian ini hendaknya dijadikan sebagai bahan acuan bagi penelitian selanjutnya untuk mengetahui seberapa besar pengaruh teknik back massage terhadap penurunan intensitas nyeri pada pasien post operasi appendiksitis. Peneliti selanjutnya, sebaiknya peneliti harus mamiliki jumlah sampel yang lebih banyak dan hendaknya dilakukan pada laki-laki saja apabila penelitinya seorang laki-laki atau pada perempuan saja bila penelitinya seorang perempuan agar tidak terjadi rasa sungkan atau segan saat tindakan dilakukan sehingga hasil yang diperoleh hasilnya lebih representative.

\section{DAFTAR PUSTAKA}

Astrani \& Fitriana, (2015). Terapi Back Massage Menurunkan Nyeri Pada Pasien Post Operasi Abdomen. Stikes_rsbaptis@yahoo.co.id

Dermawan \& Rahayuningsih, (2017). Keperawatan Medikal Bedah (Sistem Pencernaan), Yogyakarta: Gosyen Publishing.

Hadija, T. R., \& Andri, (2016). Pengaruh Teknik Relaksasi Nafas Dalam Terhadap Penurunan Skala Nyeri Pada Pasien Pasca Apendiktomi di Ruang Bedah Laki RSUD. DR. M. Haulussy Ambon Tahun 2016. http://jurnal.stikesmalukuhusada.ac.i d/index.php/jk.

Kasron \& Susilawati, (2018). Anatomi Fisiologi dan Gangguan Sistem Pencernaan. Jakarta Timur: CV. Trans Info Media.

Irianto, (2014). Anatomi dan Fisiologi. Bandung: Penerbit Alfabeta. 
Judha, S., \& Fauziah, (2015). Teori Pengukuran Nyeri \& Nyeri Persalinan, Yogyakarta: Nuha Medika.

Mardalena, (2018). Asuhan Keperawatan Pada Pasien Dengan Gangguan Sistem Pencernaan. Yogyakarta: Pustaka Baru Press.

Mander, (2016). Nyeri Persalinan, Jakarta: Buku Kedokteran EGC.

Notoatmodjo, S. (2016). Metodologi Penelitian Kesehatan, Jakarta: Rineka Cipta.

Ratu \& Adwan, (2016). Penyakit Hati, Lambung, Usus, dan Ambeien, Yogyakarta: Nuha Medika.

Sulung \& Rani, (2017). Teknik Relaksasi Genggam Jari Terhadap Intensitas Nyeri Pada Pasien Post Appendiktomi.

Suratun \& Lusianah, (2016). Asuhan Keperawatan Klien Gangguan Sistem Gastrointestinal, Jakarta: CV. Trans Info Media.

Trisnowiyanto, (2012). Ketrampilan Dasar Massage, Yogyakarta: Nuha Medika.

Wirya \& Sari, (2013). Pengaruh Pemberian Masase Punggung dan Teknik Relaksasi Nafas Dalam Terhadap Penurunan Intensitas Nyeri Pada Pasien Post Appendiktomi Di Zaal C Rs Hkbp Balige Tahun 2011. Sumut, Akper HKBP Balige. 